\title{
Three Unrecorded Muricid Species from Korean Waters
}

\author{
Hyun-Jong Kil, Jun-Sang Lee ${ }^{1}$ and Dong-Bum Koh² \\ National Institute of Biological Resources, Incheon 404-708 \\ ${ }^{1}$ Institute of Environmental Research, Kangwon National University, Chunchon 200-701 \\ ${ }^{2}$ JeJu Hanbit Psychiatric Clinic, 560, Samdo-dong, Jeju-shi 690-031
}

\begin{abstract}
The Korean muricid snails are listed include previous record and three unrecorded species, Morula iostoma, Coralliophila morishimai, and C. abnormis collected from Mudo of Jeju-do were redescribed. As a result, the family Muricidae in Korea turned out to be 44 species of 22 genera.
\end{abstract}

Key words: Muricidae, Morula iostoma, Coralliophila morishimai, Coralliophila abnormis.

\section{INTRODUCTION}

Muricid snails are one of the most diverse group among the marine predatory snails and more than 2,500 species are known (Choe and Park, 1997). They are small to large-sized, have highly variable shells of rarely smooth, usually being elaborately sculptured with spiral and axial ribs. Family Muricidae has been split by many workers into several families and subfamilies. But Ponder and Warén (1988) recognised only the Muricinae, Thaidinae and Coralliophilinae.

Since Adams and Reeve (1848) reported three muricid species for the first time in Korea, Schrenck (1867), Smith (1879), Hirase (1907), Nomura and Hatai (1928), Shiba (1934), Yoo (1959), Kim and Rho (1969), Kang et al. (1971), Kwon et al. (1993), Choe and Park (1997), Lee and Min (2002) have been reported a total of 41 species of 22 genera. However, list of entire species from each papers are not generalized and three unrecorded species are newly found from Jeju-do. As a results, 44 species of 22 genera are listed including previous record and three unrecorded which species are redescribed here.

Received: November 18, 2012 ; Accepted: December 3. 2012

Corresponding author: Jun-Sang Lee

Tel: +82 (33) 250-7409 e-mail: sljun@kangwon.ac.kr $1225-3480 / 24456$

\section{RESULT}

Throughout this study, 44 species of 22 genera including previous records were identified. Among them, Morula iostoma, Coralliophila morishimai, and C. abnormis are new to the Korean fauna and marked with asterisks in the list.

\section{LIST OF SPECIES}

Class Gastropoda Cuvier, 1791 복족강

Superorder Caenogastropoda Cox, 1959 신생복족상목 Infraorder Neogastropoda Wenz, 1929 신복족하목 Family Muricidae Rafinesque, 1815 뿔소라과

1. Haustellum sobrinus (A. Adams, 1863) 곤봉뿔소라

2. Chicoreus asianus (Kuroda, 1942) 뿔소라

3. Homalocantha anatomica (Perry, 1811)은행잎뿔고둥

4. Rapana bezoar (Linné, 1767) 좀피뿔고둥

5. Rapana venosa venosa (Valenciennes, 1846) 피뿔고둥

6. Rapana venosa pechiliensis Grabau and Kiong, 1928 황해피뿔고둥

7. Morula spinosa (H. and A. Adams, 1853) 가시뿔고둥 *8. Morula iostoma (Reeve, 1845) 보라입실패뿔고둥 (신칭)

9. Muricopsis interserrata (Sowerby, 1879) 작은가시뿔고 둥

10. Boreotrophon clathratus gunneri (Loven, 1846) 원 통날개지느러미뿔고둥

11. Boreotrophon beringi Dall, 1902 높은탑지느러미뿔고둥

12. Boreotrophon candelabrum (Reeve, 1848) 지느러미 뿔고둥 


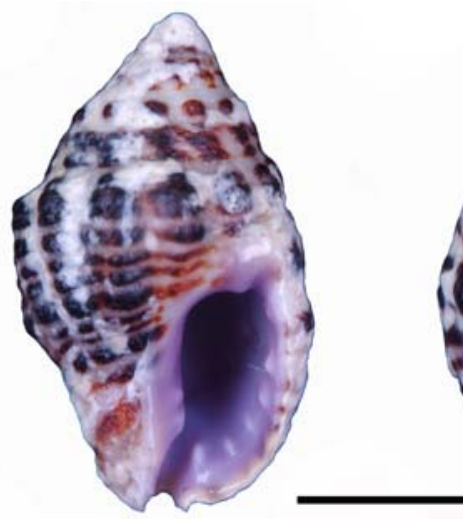

A

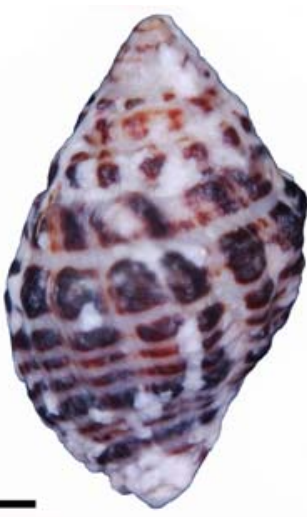

B

Fig. 1. Morula iostoma. A. Ventral view; B. Dorsal view. Scale Bar $=5 \mathrm{~mm}$.

13. Boreotrophon paucicostatus Habe and Ito, 1965 넓 은지느러미뿔고둥

14. Boreotrophon xestra xestra Dall, 1918 긴입술지느러 미뿔고둥

15. Boreotrophon pacificus pacificus Dall, 1902 지느러 미둥근뿔고둥

16. Boreotrophon pacificus aomoriensis (Nomura and Hatai, 1940) 밤색지느러미작은뿔고둥

17. Boreotrophon cymatus Dall, 1902 갈색입지느러미뿔 고둥

18. Boreotrophon alaskanus Dall, 1902 알라스카지느러 미고둥

19. Nipponotrophon scitulus (Dall, 1891) 격자무늬작은 고둥

20. Siphonochelus japonicus (A. Adams, 1863) 굴뚝뿔고둥

21. Ceratostoma burnetti (Adams and Reeve, 1850) 입 뿔고둥

22. Ceratostoma fournieri (Crosse, 1861) 세뿔고둥

23. Ceratostoma rorifluum (Adams and Reeve, 1850) 맵사리

24. Ceratostoma inornatum (Récluz, 1851) 어깨뿔고둥

25. Ocinebra lumaria (Yokoyama, 1920) 주름어깨뿔고둥

26. Murex endermonis E. A. Smith, 1875 날개어깨뿔고둥

27. Pteropurpura falcata falcata (Sowerby, 1841) 대롱 뿔고둥

28. Pteropurpura adunca adunca (Sowerby, 1834) 날개 뿔고둥

29. Genkaimurex varicosa Kuroda, 1953 주름뿔고둥

30. Lataxiena fimbriata (hinds, 1844) 잔가시뿔고둥

31. Bedeva birileffi (Lischke, 1871) 입주름뿔고둥
32. Ergalatax contracta contracta (Reeve, 1846) 탑뿔고둥

33. Maculotriton serriale serriale (Deshayes, 1834) 꼬 마흑점밀알고둥

34. Mancinella echinata (Blainville, 1832) 밤송이두드럭 고둥

35. Thais gradata (Jonas, 1846) 모난어깨두드럭고둥

36. Thais bronni (Dunker, 1860) 두드럭고둥

37. Thais clavigera (Küster, 1860) 대수리

38. Thais luteostoma (Holten, 1803) 뿔두드럭고둥

39. Necella heyseana (Dunker, 1882) 옆주름고둥

40. Nucella freycineti freycineti (Deshayes, 1839) 팽이 옆주름고둥

41. Nucella lamellosa hormica Dall, 1915 지느러미옆주 름고둥

42. Coralliophila rubrococcinea Melvill and Standen, 1901 담갈색잔고리고둥

*43. Coralliophila morishimai Kuroda and Shikama, 1966 동범산호살이고둥

*44. Coralliophila abnormis (E. A. Smith, 1879) 굵은이 랑잔줄산호살이고둥

\section{DESCRIPTION OF SPECIES}

Class Gastropoda Cuvier, 1791 복족강

Superorder Caenogastropoda Cox, 1959 신생복족상목 Infraorder Neogastropoda Wenz, 1929 신복족하목

Family Muricidae Rafinesque, 1815 뿔소라과

Genus Morula Schumacher, 1817 실패뿔고둥속(신칭)

Morula iostoma (Reeve, 1845) 보라입실패뿔고둥(신칭)( Fig. 1).

Ricinula iostoma Reeve, 1845 , p. 192, sp. 37, pl. V. 


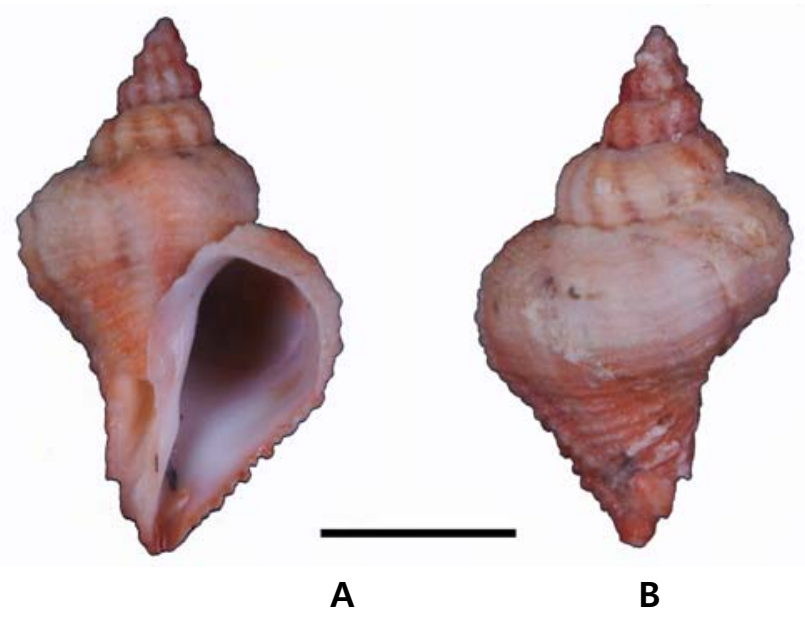

Fig. 2. Coralliophila morishimai. A. Ventral view; B. Dorsal view. Scale Bar $=10 \mathrm{~mm}$.

Thiphoris purpuratus Pilsbry, 1895, p. 58.

Morula iostoma Higo et al., 1999, p. 210; Okutani, 2000, p. 393, fig. 144 .

Type locality. None designated.

Materials examined. 2 individuals, 7 October 2003, 12 $\mathrm{m}$ in depth, Saekkiseom, Seogwipo-si, Jeju-do (33¹3'38.80"N, 126³4'5.6"E).

Measurement. $5.8 \mathrm{~mm}$ in height; $1.7 \mathrm{~mm}$ in width. Description. Shell globose, small size. Thick and inflated. Periostracum white color. Whorls 9 in number. Apex worn out but evident. Spire low, two rows of spiral cord on each whorl. Suture deep. Spiral cord about 10 in number on body whorl, interval getting narrower to base. Shoulder weakly angulated. Thick axial ribs 12 in number, crossed by spiral cords. Nodules black color. Aperture oval in shape, laterally narrow. purplish within with 5-6 denticles on outer lip, 2 on lower portion of axial lip. Callus knob inflated. Siphonal canal open.

Habitat. Gravel bottom about 10-50 m in depth.

Distribution. Korea, Japan, Philippine.

Genus Coralliophila H. and A. Adams, 1853 산호살이고 둥속

Coralliophila morishimai Kuroda and Shikama, 1966 동범산호살이고둥 (신칭)(Fig. 2).

Coralliophila morishimai Shikama, 1966, p. 22, pl. 1, fig. 3; Higo et al., 1999, p. 216; Okutani, 2000. p. 415, fig. 269.
Type locality. Cape Shio, Kii Peninsula.

Materials examined. 1 individuals, 4 October 2003, 17 $\mathrm{m}$ in depth, Saekkiseom, Seogwipo-si, Jeju-do $\left(33^{\circ} 13^{\prime} 38.80 " \mathrm{~N}, 126^{\circ} 34^{\prime} 5.6^{\prime \prime} \mathrm{E}\right)$

Measurement. $27.0 \mathrm{~mm}$ in height; $17.0 \mathrm{~mm}$ in width. Description. Shell small size, inflated spindle shape, not thick but solid. Periostracum light yellowish orange color. Spire narrow and steeply high. Body whorl strongly inflated laterally. Whorls 6 in number. Suture deep. Axial ribs 10 in number, obscure in body whorl but prominent from penultimate whorl to apex. Shoulder highly angulated. Deep and distinct spiral keels sculptured with interval and fine spiral striae locate between keels. Base laminated. Aperture broad. Outer lip crenulated with spiral keels. Axial lips wide and detached from body whorl. Fasciole narrow. Siphonal canal open.

Habitat. Intertidal zone to rocky bottom of $50 \mathrm{~m}$ in depth.

Distribution. Korea, Japan.

Coralliophila abnormis E. A. Smith, 1878 굵은이랑잔줄 산호살이고둥 (신칭) (Fig. 3).

Fusus abnormis E. A. Smith, 1878, p. 811, pl. L, fig. 10.

Coralliophila abnormis Higo et al., 1999, p. 217; Okutani, 2000. p. 419, fig. 288; Poppe, 2008, p. 244, pl. 417, figs. 4-6.

Type locality. Off Port Blair, Andaman Island. 


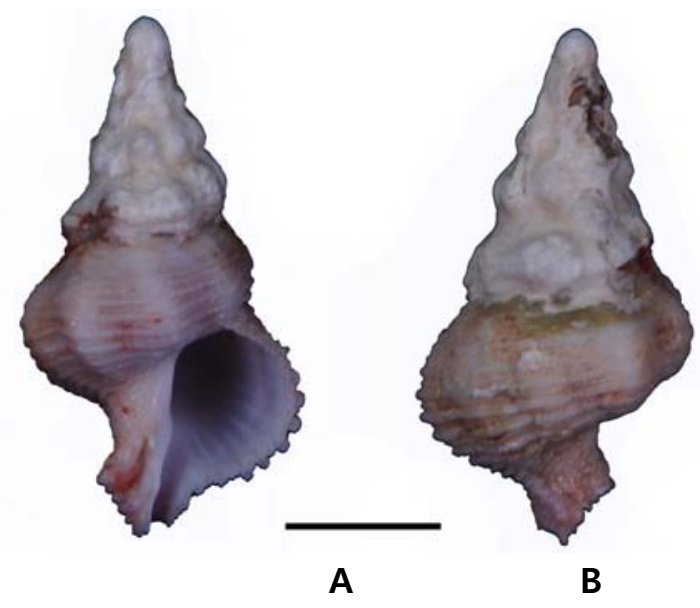

Fig. 3. Coralliophila abnormis. A. Ventral view; B. Dorsal view. Scale Bar $=10 \mathrm{~mm}$.

Materials examined. 2 individuals, 16 November 2003, $15 \mathrm{~m}$ in depth, Munseom, Seogwipo-si, Jeju-do (33ำ 13 '38.6"N, $\left.126^{\circ} 34^{\prime} 4.10^{\prime \prime} \mathrm{E}\right)$.

Measurement. $33.5 \mathrm{~mm}$ in height; $18.0 \mathrm{~mm}$ in width. Description. Shell small size, pale purplish red color. Spire steeply high. Whorls 8 in number. Periphery of every spire strongly inflated. Suture oblique, deeply channeled and distinct. Axial ribs 8 in number, broad and prominent. Spiral keels deeply sculptured with regular interval and numbers getting increase to body whorl. Aperture circle in shape, outer lip crenulated with spiral keels. Fasciole strongly folded and laminated. Siphonal canal short and twisted. Interior weakly purple in color.

Habitat. Intertidal zone to rocky bottom of $150 \mathrm{~m}$ in depth.

Distribution. Korea, Japan, Philippines, Indian Ocean.

\section{Acknowledgment}

This study was supported by Discovery of Korean Indigenous Species Project, NIBR (National Institute of Biological Resources).

\section{REFERENCES}

Adams, H. and Reeve, L. (1848) Mollusca. In; Adams A (ed.), The Zoology of the Voyage of H.M.S. Samarang: under the command of Captain Sir Edward Belcher, C. B., F. R. A. S., F. G. S. during the years 1843-1846. Reeve, Benham and Reeve, London. pp. 1-87.

Choe, B.L. and Park, J.K. (1997) Description of muricid species (Gastropoda: Neogastropoda) collected from the coastal areas of South Korea. Korean Journal of Biological Science, 1: 281-296.

Hirase, Y. (1907) On Japanese marine Mollusca. Conchological Magazine, 1: 55-73.

Higo, S., Callomon, P. and Goto, Y. (1999) Catalogue and bibliography of the marine shell bearing mollusca of Japan. Elle Scientific Publications. Osaka, Japan. 749 pp.

Kang, Y.S. (1971) Nomina Animalium Koreanorum. Hyang Moon Co, Seoul. Vol. 3, pp. 1-180.

Kim, H.S. and Rho, B.J. (1969) The seashore marine fauna of Chuja Island, Korea. In: A Report on the Floral and Faunal Survey of Chuja Island. Office of Cultural Properties, Korea Ministry of Culture and Information, Seoul, pp. 27-108.

Kwon, O.K., Park, G.M. and Lee, J.S. (1993) Coloured Shells of Korea. Academy Pub. Co., Seoul, Korea. pp. 1-445.

Lee, J.S. and Min, D.K. (2002) A catalogue of molluscan fauna in Korea. Korean Journal of Malacology, 18(2): 93-217.

Nomura, S. and Hatai, K. (1928) On the distribution of Mollusca from Korean coast. Journal of Chosen Natural History Society, 6: 92-100.

Okutani, T. (2000) Marine mollusks in Japan. Tokai Univ. Tokyo. pp. 1-1171. [In Japanese and English].

Pilsbry, H.A. (1895) Catalogue of the marine mollusks of Japan with descriptions of new species and notes on others collected by Frederick Stearns. Viii $+196 \mathrm{pp}$, 11pls.

Ponder, W.F and Warén, A. (1988) Appendix. Classification of the Caenogastropoda and Heterostropha - a list of the family-group names, and higher taxa. 288-328 In; Ponder, W.F (ed.) Prosobranch Phylogeny. Malacological Review, Supplement 4.

Poppe, G.T. (2008) Philippine Marine Mollusks. Vol. II. Gastropoda - Part. 2. ConchBooks. Hackenheim, 
Germany. pp. 1-848.

Reeve, L.A. (1845) Conchologia Iconica. Vol. III. London. pp. 237, 14 pls.

Schrenck, L. von. (1867) Reisen und Forschungen im Amurlande in den Jahren 1854-1856, 2(3), Mollusken des Amurlandes und des Nordjapanischen Meeres. St. Petersburg. pp. 259-974.

Shiba, N. (1934) Catalogue of the Mollusca of Chosen (Corea). Journal of Chosen Natural History Society, 18: $6-31$.
Shikama, T. (1966) On some new Latiaxix and Coralliophila in Japan. Venus, 25(1): 21-26

Smith, E.A. (1878) On a collection of marine shells from the Andaman Islands. Proceedings of the Zoological Society of London, III. pp. 804-820, pls. L.

Yoo, J.S. (1959) Description of unrecorded species of molluscan shells in Korea. Korean Journal of Zoology, 2: 29-33. 